\title{
Regulation of oxytocin receptor in the placentome capsule throughout pregnancy in the ewe: the possible role of oestradiol receptor, progesterone receptor and aromatase
}

\author{
S T Leung, T S Reynolds and D C Wathes \\ Department of Veterinary Basic Sciences, The Royal Veterinary College, Boltons Park, Hawkshead Road, Potters Bar, Hertfordshire, EN6 1NB, UK \\ (Requests for offprints should be addressed to D C Wathes)
}

\begin{abstract}
The hormonal regulation of uterine oxytocin receptors (OTR) during the establishment of pregnancy and at parturition has been studied extensively, but little information is available during mid-pregnancy. This study investigated the localisation of OTR mRNA in the ovine placentome throughout gestation and related this to expression patterns for the putative regulatory agents aromatase, oestradiol receptor, progesterone receptor and oxytocin. Placentomes were collected at regular intervals throughout pregnancy for in situ hybridisation analysis and immunocytochemistry (oestradiol receptor only). Results were quantified by optical density measurements of autoradiographs. Progesterone receptor mRNA was localised to the caruncular tissues on day 30 but became undetectable by day 34. Aromatase mRNA appeared in the fetal villi at days $34-40$, with concentrations peaking at days 52-55 and again at days 132-137. Oestradiol receptor mRNA was localised to the caruncular tissues from days 13 to 30 and found in the maternal villi and placentome
\end{abstract}

capsule from days 45 to 70 . Oestradiol receptor protein was barely detectable in either tissue. OTR mRNA was localised to the placentome capsule at days 34-40, remaining high at day 45 and declining to basal levels by days 132-137. Oxytocin mRNA was not detected in the placentome. In conclusion: (1) progesterone acting via its receptor may suppress the expression of aromatase and OTR in early pregnancy; (2) the up-regulation of OTR expression in the capsule may not involve the oestradiol receptor; (3) there is a differential regulation between different regions of the uterus as the increase in the placentome capsule occurs at a time when concentrations in the rest of the endometrium and myometrium remain low; (4) oestradiol receptor expression in the placentome may be regulated at the translational level; and (5) there is no local production of oxytocin in the sheep placenta. The role of OTRs in the capsule during mid-pregnancy remains to be determined.

Journal of Endocrinology (1998) 158, 173-181

\section{Introduction}

The development of endometrial oxytocin receptors (OTR) plays an important role in inducing the production of prostaglandin $(\mathrm{PG}) \mathrm{F}_{2 \alpha}$ during luteolysis in cyclic ewes. Inhibition of these receptors is an essential step in the maternal recognition of pregnancy (for reviews see Stewart et al. 1992, Flint et al. 1994, Wathes \& Lamming 1995). Oxytocin induced myometrial contractions of the reproductive tract, mediated by OTR, are also important to facilitate delivery of the fetus during parturition (Owiny et al. 1992, Word et al. 1992, Kimura et al. 1996). The regulation and role of OTR at these two time periods have, therefore, been investigated extensively. Fewer studies, however, have examined the period in between, that encompassing most of pregnancy.

We have reported previously that OTR mRNA is present in the uterine tissues and the capsule of the placentome during mid-pregnancy in sheep (Wathes et al. 1996a). The capsule is a layer of maternal connective tissues rich in collagen and fibroblast surrounding the placentome which becomes distinguishable at around day 35 of pregnancy. OTR expression, both mRNA and protein, increases significantly at around day 70 and again at parturition in the endometrium and myometrium (Fuchs et al. 1992, Wathes et al. 1996a, Wu et al. 1996). In contrast, the concentration of OTR mRNA in the capsule of the placentome elevates significantly at around day 40 when its expression in the endometrium and myometrium are low (Wathes et al. 1996a). Therefore, a differential regulation of the expression of OTR must exist between these different regions along the reproductive tract.

Aromatase plays an important role in converting progesterone to oestrogen in the placenta (Flint et al. 1975, Mason et al. 1989). The modulation of the concentration of these steroid hormones may have a profound effect on the development of their receptors since oestradiol stimulates 
the expression of the oestradiol receptor (Fang et al. 1996, Ing et al. 1996, Katzenellenbogen 1996, Ing \& Tornesi 1997). Although the increase in free oestradiol concentration is only significant at term, aromatase may be responsible for the gradual increase in oestradiol sulphate, which can be unconjugated to produce free oestrogen (Mitchell et al. 1984, Chibbar et al. 1986, Janszen et al. 1995). In order to understand the possible role of aromatase during pregnancy, it is necessary to examine its expression pattern and site of synthesis.

Oestradiol and progesterone may play a role in opposing and facilitating the establishment of pregnancy respectively. It is generally believed that oestradiol and progesterone induce and suppress the expression of OTR respectively (Maggi et al. 1991, Ostrowski et al. 1995, Larcher et al. 1995, Wathes et al. 1996b). Although the oestrogen and progesterone concentrations in sheep have been monitored throughout pregnancy (Bassett et al. 1969, Carnegie \& Robertson 1978), little is known about the development of their receptors during mid-pregnancy. Therefore, the investigation of the sites of expression of oestradiol and progesterone receptors in the placenta of sheep may help us to understand the possible role of these steroids in achieving differential regulation of expression of OTR during pregnancy.

The aims of this experiment were to localise and correlate the expression patterns of aromatase, oestradiol receptor, progesterone receptor, oxytocin and OTR mRNA in the ovine placentome using in situ hybridisation throughout pregnancy. Immunocytochemistry was also carried out to investigate the translation of the oestradiol receptor message.

\section{Materials and Methods}

\section{Animals}

Clun Forest ewes were run with entire rams and raddle marks were checked to indicate mating (day 0). The gestation length of sheep is between 145 and 147 days. Ewes were slaughtered by an overdose of pentobarbitone i.v. (Euthatal, Tallaght, Dublin, Ireland). Tissues were collected within 15 min of slaughter at the following stages of pregnancy: days 13-15 $(n=4)$, days 21-22 $(n=4)$, days 29-30 $(n=4)$, days 34-40 $(n=3)$, days $45-46(n=3)$, days 52-55 $(n=5)$, days $65-70(n=7)$, days $90-105(n=6)$ and days 132-137 $(n=7)$. Pieces of placentome were removed, wrapped in aluminum foil, frozen in isopentane immersed in liquid nitrogen and stored at $-80{ }^{\circ} \mathrm{C}$. Samples were also obtained from non-pregnant ewes at oestrus $(n=4)$ and on day 9 of the cycle $(n=3)$.

\section{Reagents}

Chemicals were purchased from Sigma Chemical Co. (Poole, Dorset, UK) or Merck (Poole, Dorset, UK) unless otherwise specified.

\section{Section preparation}

Cross sections $(10 \mu \mathrm{m})$ were cut and thaw mounted on poly-L-lysine $\left(0 \cdot 1 \mathrm{mg} \mathrm{ml}^{-1}\right)$ coated slides. The sections were fixed in $4 \% \mathrm{w} / \mathrm{v}$ paraformaldehyde $(\mathrm{BDH}$, Poole, Dorset, UK) in $1 \times$ phosphate-buffered saline (PBS, $0.13 \mathrm{M} \mathrm{NaCl}, 0.007 \mathrm{M} \mathrm{Na}_{2} \mathrm{HPO}_{4}$ ) for $5 \mathrm{~min}$, washed in $1 \times$ PBS for $2 \mathrm{~min}(3 \times)$ and dehydrated in $75 \%$ followed by $95 \%$ absolute ethanol for $5 \mathrm{~min}$ each. The sections were then stored in $95 \%$ absolute ethanol at $4{ }^{\circ} \mathrm{C}$ until used.

\section{In situ hybridisation}

The in situ hybridisation procedures were applied as previously described (Wathes et al. 1996a). Briefly, the mRNA specific probes (antisense; 45 mer synthetic oligonucleotide), were end labelled with dATP-S ${ }^{35}$ (NEN Research Products, Stevenage, Herts, UK). The reaction mix containing the labelled probes in hybridisation buffer (100 K c.p.m. per $100 \mu \mathrm{l}$ hybridisation buffer per slide) was added to the sections, covered with a parafilm coverslip, and incubated at $43{ }^{\circ} \mathrm{C}$ overnight. After incubation, the sections were washed at room temperature for $30 \mathrm{~min}$ followed by $1 \mathrm{~h}$ at $55^{\circ} \mathrm{C}$ in $1 \times$ sodium saline citrate (SSC; $15 \mathrm{mM}$ sodium chloride, $15 \mathrm{mM}$ sodium citrate, $\mathrm{pH} 7 \cdot 0)$ containing $0 \cdot 2 \%(\mathrm{w} / \mathrm{v})$ sodium thiosulphate-5 hydrate. The slides were then dehydrated in a gradient of ethanol, air-dried and exposed to hyperfilm- $\beta \max$ (Amersham International plc, Amersham, Bucks, UK) for the defined period (see below). The sense sequence of the respective probe was used as the negative control. The uterus of a ewe at oestrus was used as the positive control for the oestradiol receptor and OTR probes, a day 2 ovine corpus luteum as the positive control for the oxytocin peptide probe and a day 2 uterus as the positive control for the progesterone receptor probe.

\section{Probes (antisense sequence)}

The probe sequences used in this study were based on published cDNA sequences. Oligonucleotide 45 mers were synthesised (Babraham Institute, Cambridge, UK) after specific sequences were chosen.

Aromatase (exposure time 2 weeks; Hinshelwood et al. 1993, bases 127-1317):

5'-TCA CCG GGT AGC CAT CGA TGA CAT CAT CCT CTA AGG CTT TGC GCA-3'

Progesterone receptor (exposure time 2 weeks; Ing et al. 1996, bases 2148-2196):

5'-CCG AAA ACC TGG CAG TGA CTT AGA CCA CTT GAC CAC TGA GAG AAG-3'

Oestradiol receptor (exposure time 3 weeks; Ing et al. 1996, bases 564-608):

5'-TGG CCT GTA GTA GGC GGG AGG GCC GGC TTC GCG CAC CGC ATA GCC-3' 
Oxytocin peptide (exposure time 2 weeks; Ivell et al. 1990, bases 770-814):

5'-AGC ACC GCA CGC TTG CCG CCC AGG GGG CAG TTC TGA ATG TAG CTG-3'

OTR (exposure time 2 weeks; Stevenson et al. 1994, bases 887-923):

5'-TTC CTT GGG CGC ATC GGC ATC CCA GAC ACT CCA CAT CTG CAG GAA-3'

\section{Photographic emulsions}

The procedures were similar to the instructions provided by the manufacturer (LM-1, Amersham International plc). Briefly, completely dried slides were dipped into the emulsion vertically for $5 \mathrm{~s}$ at $43{ }^{\circ} \mathrm{C}$ and allowed to dry horizontally at room temperature and then on a pre-cooled metal plate, with dry ice underneath, for $10 \mathrm{~min}$ each. The slides were then placed into a light-tight box with anhydrous silica gel in the base of the box, sealed, and incubated at $4{ }^{\circ} \mathrm{C}$ until developing. The incubation time depended on the probe used: (a) aromatase, (b) progesterone receptor, (c) oxytocin peptide, (d) OTR for 3 weeks, and (e) oestradiol receptor for 4 weeks. After incubation, the slides were dipped in developer (Phenisol; Ilford Limited; Ilford, UK) for $5 \mathrm{~min}$, stop bath ( $0.5 \%$ acetic acid $\mathrm{v} / \mathrm{v})$ for $1 \mathrm{~min}$, fixative $(47 \% \mathrm{w} / \mathrm{v}$, sodium thiosulphate pentahydrate) for $10 \mathrm{~min}$ and then distilled water for at least $10 \mathrm{~min}$ before counterstaining with Harris' haematoxylin (BDH) and eosin (Sigma) to identify the cell types.

\section{Oestradiol receptor localisation}

Immunocytochemistry was carried out on placentomes collected at days 21-22, 29-30, 40-46, 52-55, 70 and 105. The procedures were applied as described previously (Wathes \& Hamon 1993). Cross sections ( $5 \mu \mathrm{m}$ thick) were cut and thaw-mounted onto 3 -aminopropyltriethoxysilane $(2 \% \mathrm{v} / \mathrm{v})$ coated slides and fixed in formaldehyde $(3 \cdot 7 \% \mathrm{v} / \mathrm{v})$ for $10 \mathrm{~min}$. The sections were then treated with acetone $(100 \%)$ and methanol $(100 \%)$ containing hydrogen peroxide $(1 \% \mathrm{v} / \mathrm{v} ; \mathrm{BDH})$ at room temperature for $5 \mathrm{~s}$ each followed by washing in $1 \times$ PBS for 5 min $(2 \times)$. All subsequent incubations were in a humidified box at room temperature unless otherwise specified. After washing, the sections were incubated with normal rabbit serum (NRS, 2.5\%; Sigma) for $10 \mathrm{~min}$. The NRS was then blotted off prior to the incubation with $100 \mu \mathrm{l}$ mouse anti-oestradiol receptor antiserum (1:80 diluted in PBS; DAKO, Ely, Cambridge, UK) at $4{ }^{\circ} \mathrm{C}$ overnight. For control sections, mouse anti-IgG $(1 \mu \mathrm{g}$ $\mathrm{ml}^{-1}$; Sigma) was added in place of anti-oestradiol receptor antiserum.

After overnight incubation, the slides were washed in $1 \times$ PBS for $5 \min (2 \times)$ before incubating with: (i) rabbit anti-mouse antiserum (1:100, Sigma) for $30 \mathrm{~min}$; then (ii) $100 \mu \mathrm{l}$ peroxidase anti-peroxidase (1:50, Sigma) for $30 \mathrm{~min}$; and (iii) $100 \mu \mathrm{l}$ activated diaminobenzidinetetrahydrochloride (DAB; $0.5 \mathrm{mg} \mathrm{ml}^{-1}$; Sigma) for 10 min in the dark. After incubation, the excess DAB was washed away by distilled water and the slides were mounted after a serial dehydration in 75\%,100\% ethanol, and xylene (100\%) for 2 min each.

\section{Data analysis}

After exposure, the in situ hybridisation images on autoradiographs were quantified by measuring the optical absorbance of specific areas identified by Harris' haematoxylin and eosin staining using an image analysis system (Seescan plc, Cambridge, Cambs, UK). The results were expressed as optical density (OD) units on an arbitrary scale with a detection limit of $0 \cdot 01$. Three readings per section and four sections per sample were taken from the probed slides. The sense values were subtracted from the antisense values to produce a mean value of specific hybridisation in each region. The immunocytochemistry results were given a score of zero (no staining) to three (very strong staining). The final results were log transformed to ensure homogeneity of variance and analysed by ANOVA followed by pooled variance $t$-test. If the data were not homogeneous, a Kruskal-Wallis test (nonparametric ANOVA) was used followed by a MannWhitney test. Values are given as the mean \pm s.E.M. Significance is defined as a $P$ value $<0 \cdot 05$.

\section{Results}

\section{Aromatase}

The oligonucleotide probe used was specific for both the ovarian and placental isoforms of aromatase. No aromatase mRNA was detected in any region of the uterus at oestrus, nor during early pregnancy before day $30(\mathrm{OD}<0 \cdot 01$; $n=12$ ). The aromatase mRNA was first localised in the fetal villi of the cotyledon at days 34-40 $(\mathrm{OD}=0.05 \pm 0 \cdot 022 ; n=5$; Fig. 1$)$, increasing significantly at days $52-55(0 \cdot 08 \pm 0 \cdot 006 ; n=5 ; P<0 \cdot 05)$ and returning to a similar concentration to that measured on days 34-46 at days 65-105 ( $n=12$; Fig. 2). Another and greater significant elevation of aromatase $\mathrm{mRNA}$ in the fetal villi was observed at days $132-137(\mathrm{OD}=0 \cdot 25 \pm 0 \cdot 071 ; n=3$; $P<0 \cdot 05$; Fig. 2). The aromatase mRNA was below the detection limit $(\mathrm{OD}<0 \cdot 01)$ in all other regions of the placentome.

\section{Oestradiol receptor}

The oestradiol receptor mRNA concentrations in the caruncle and luminal epithelium (LE) of the uterus at oestrus were $0 \cdot 24 \pm 0 \cdot 049(n=4)$ and $0 \cdot 12 \pm 0 \cdot 022(n=4)$ 

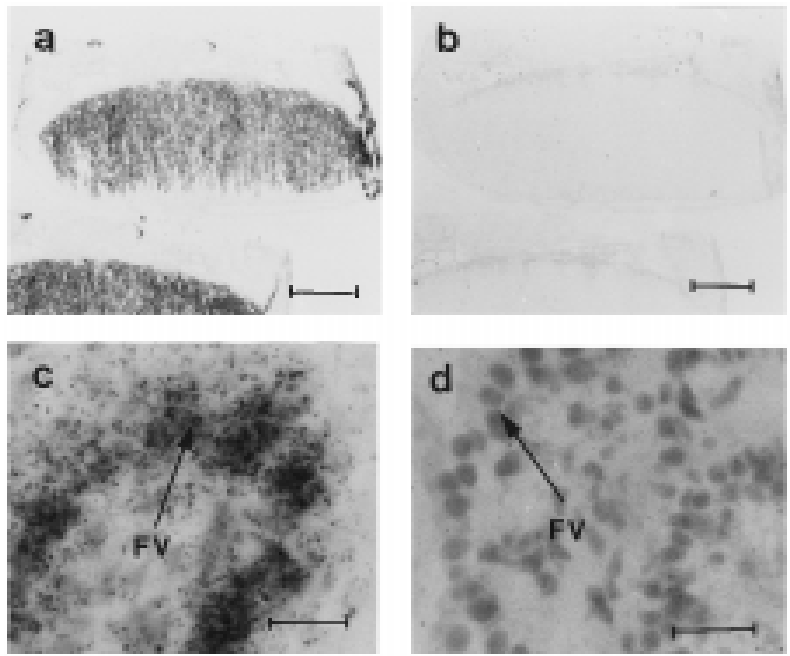

Figure 1 The expression of aromatase mRNA was localised using in situ hybridisation. An ovine specific antisense probe was hybridised with a cross section of placentome on day 135 of pregnancy (a). The specific site of expression was examined by photographic emulsion (c). Aromatase mRNA was expressed in the fetal villi (FV). The sense sequence was used as the negative control ( $b$ and d). The scale bars represent $23 \mathrm{~mm}$ ( $a$ and $b$ ) and $10 \mu \mathrm{m}$ (c and d) respectively.

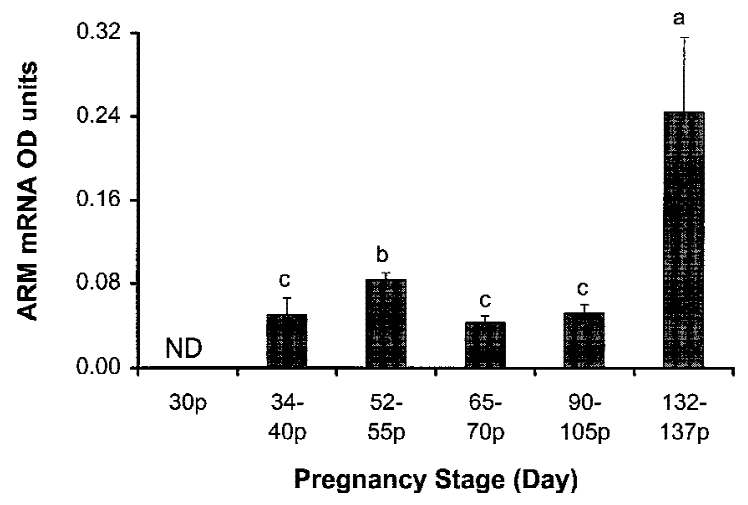

Figure 2 The expression of aromatase (ARM) mRNA in the placentome throughout pregnancy was investigated using in situ hybridisation. Samples were obtained at regular time intervals throughout pregnancy $(p ; n=3-7$ per stage). The concentration of the ARM mRNA in the fetal villi was measured on the autoradiographs and expressed as mean \pm S.E.M. OD units. Aromatase expression was not detectable (ND) in either the fetal cotyledon or maternal caruncle on day 30 of pregnancy. A low concentration of ARM mRNA was expressed when the placentome was first recognised at around days 34-40 of pregnancy. A significant increase in ARM concentration was observed at days 52-55 which returned to a lower level by day 65 until a second peak was observed at around day 135 of pregnancy. (a>b, $P<0 \cdot 05 ; b>c, P<0 \cdot 05 ; a>c, P<0 \cdot 01)$.

OD units respectively. During early pregnancy, from day 13 to day 30, a low concentration of oestradiol receptor mRNA was localised in the caruncular tissues. As pregnancy progressed and the placentome became bigger, the
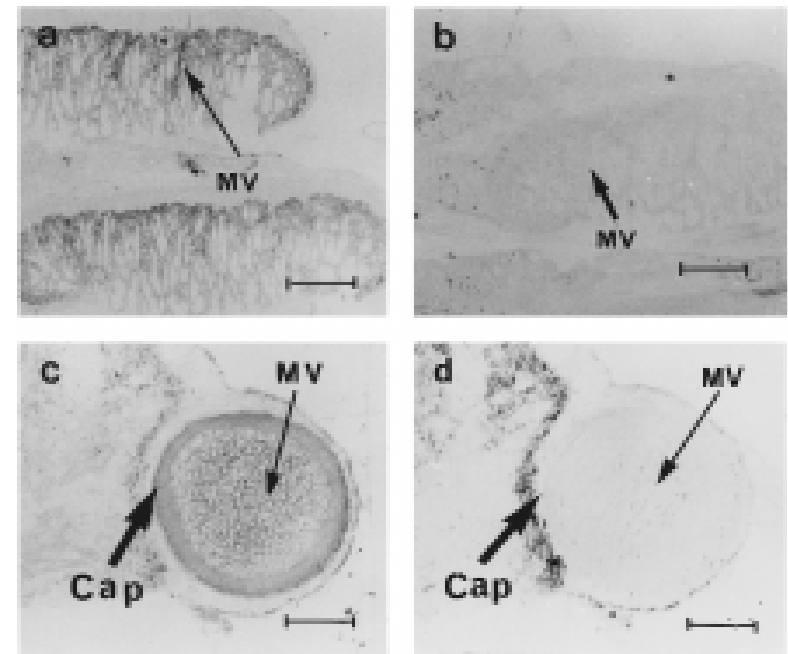

Figure 3 The expression of oestradiol receptor mRNA in the placentome was investigated using in situ hybridisation. A cross section of the placentome (day 45 of pregnancy) was hybridised with an antisense ovine specific probe. The results showed that oestradiol receptor was expressed in the maternal villi (MV; a and b) and in the placentome capsule (Cap; c and d). The sense sequence was used as the negative control (b and $d$ ). The scale bars represent $35 \mathrm{~mm}$.

results showed that the mRNA signal originated in the maternal villi (Fig. 3). The concentration of oestradiol receptor mRNA in the maternal villi was highest at days 34-46 (0.07 $\pm 0 \cdot 01)$ but became undetectable by day 90 of pregnancy (Fig. 4). It was also localised in the placentome capsule, first appearing on day $45(P<0 \cdot 001$; Fig. 3$)$, then progressively decreasing from days 52 to 70 and disappearing by day 90 of pregnancy (Fig. 5). A low level of oestradiol receptor mRNA was observed in early pregnancy in the LE on day $13(0.03 \pm 0 \cdot 008)$, reaching basal levels by days 21 to 30 . It then became undetectable throughout the rest of the study period (data not shown).

The concentration of oestradiol receptor protein in the uterus from a ewe at oestrus (used as a positive control) scored two and three in the endometrial LE and myometrium respectively (data not shown). These values are comparable with those reported previously (Wathes \& Hamon 1993). No oestradiol receptor protein was detected in either the LE nor the glandular epithelium at any stage of pregnancy examined (days 21-105). In contrast, a low concentration of oestradiol receptor protein was detected in the maternal villi (scored $0 \cdot 41 \pm 0 \cdot 148$, $n=11$ ) from days 40 to 105 of pregnancy. This subsequently disappeared. Oestradiol receptor protein was also found in the capsule at a similar low concentration (scored $0 \cdot 67 \pm 0 \cdot 235, n=11$ ) from days 40 to 105 of pregnancy.

\section{Progesterone receptor}

A very low concentration of progesterone receptor mRNA $(0 \cdot 02 \pm 0 \cdot 006, n=3)$ was localised in the caruncular tissues 


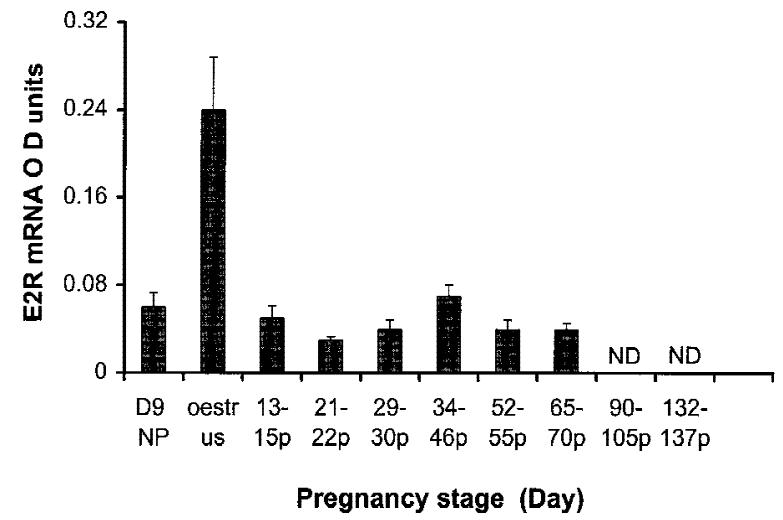

Figure 4 The expression of oestradiol receptor (E2R) mRNA in the maternal caruncles or villi was localised by in situ hybridisation. A uterus from an oestrous sheep was used as the positive control to illustrate the relative degree of expression between cyclic and pregnant ewes. The results were expressed as mean \pm S.E.M. OD units measured from autoradiographs. Samples were collected at regular time intervals throughout pregnancy $(p, n=3-7$ per stage) or during the oestrous cycle (NP, $n=3-4$ per stage). Low E2R mRNA expression was found in the caruncular tissues on day 13 of pregnancy until day 34, when the placentome could be recognised histologically. No significant variation was observed in the maternal villi until day 70 of pregnancy. However, E2R mRNA was below detection (ND) from day 90 until day 137 of pregnancy.

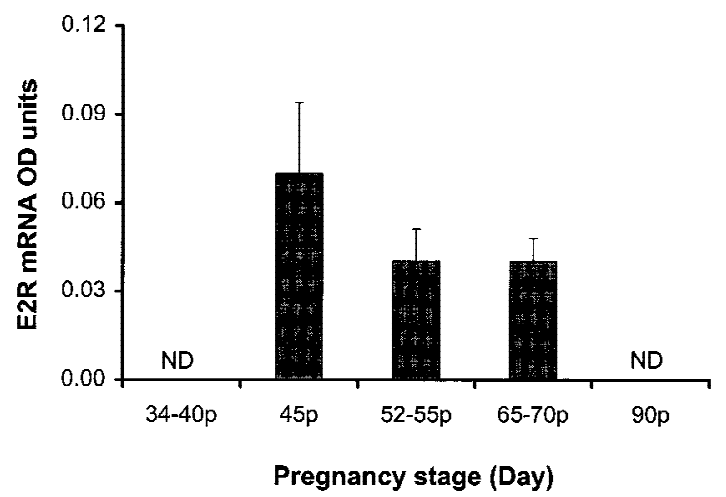

Figure 5 The expression of oestradiol receptor (E2R) mRNA in the placentome capsule was studied throughout pregnancy at regular time intervals $(p ; n=3-7$ per stage). The results were expressed as mean \pm S.E.M. OD units. No E2R mRNA was detected in the placentome capsule on days 34-40 of pregnancy (ND). However, a significant increase in E2R mRNA was observed on day 45 $(P<0 \cdot 001)$, with concentration remaining high until days $65-70$ and becoming undetectable (ND) by day 90 .

on day 30 of pregnancy (data not shown). It was undetectable by day 34 and throughout the rest of the period studied. In contrast, progesterone receptor mRNA was highly expressed in the deep and superficial uterine glands of a ewe on day 2 of the oestrous cycle (control tissue, $\mathrm{OD}=0 \cdot 25 \pm 0.083$ and $0 \cdot 37 \pm 0 \cdot 112$ respectively) but was not expressed in the myometrium, LE nor caruncle at this stage.
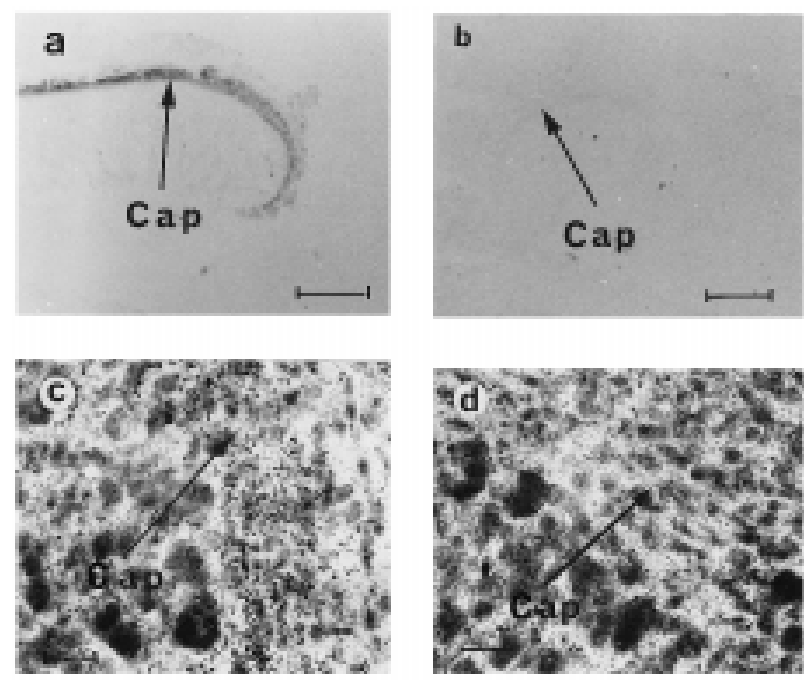

Figure 6 The expression of OTR mRNA in the placentome was investigated using in situ hybridisation. An antisense ovine specific probe was hybridised with a cross section of the placentome at day 45 of pregnancy (a). The site of expression was localised using photographic emulsion (c). The results showed that OTR was strongly expressed in the capsule (Cap) of the placentome. The sense sequence was used as the negative control (b and d). The scale bars represent $45 \mathrm{~mm}$ ( $\mathrm{a}$ and $\mathrm{b}$ ) and $10 \mu \mathrm{m}$ (c and d) respectively.

\section{Oxytocin receptor and oxytocin}

There was a significant variation of OTR mRNA concentrations in the capsule layer of the placentome throughout pregnancy (ANOVA; $P<0 \cdot 001$ ). OTR mRNA first appeared in the capsule on day 35 of pregnancy $(P<0 \cdot 0001)$ at around the time when the capsule layer could be distinguished histologically (Fig. 6). The concentration remained high at days 45-46 $(P<0 \cdot 0001)$ and then progressively decreased from days 52 to 55 , reaching basal levels by day 132 (Fig. 7). The peak OTR mRNA concentration in the capsule in mid-pregnancy was equivalent to that measured in the LE and myometrium during labour (Wathes et al. 1996a). No oxytocin mRNA was detectable in any region of the placentome throughout pregnancy $(\mathrm{OD}<0 \cdot 01)$ whereas the corpus luteum from a ewe on day 2 of the oestrous cycle (positive control) showed a high concentration of oxytocin mRNA $(\mathrm{OD}=1 \cdot 31 \pm 0 \cdot 179)$.

\section{Discussion}

Progesterone is an essential hormone required to maintain pregnancy. Oestrogen becomes the dominant hormone at parturition in the ewe, when it induces cervical ripening (Ellwood 1980, Winn et al. 1994, Cheah et al. 1995, Silva et al. 1995) and the formation of myometrial gap junctions (Garfield et al. 1980, Ciray et al. 1996). Although the 


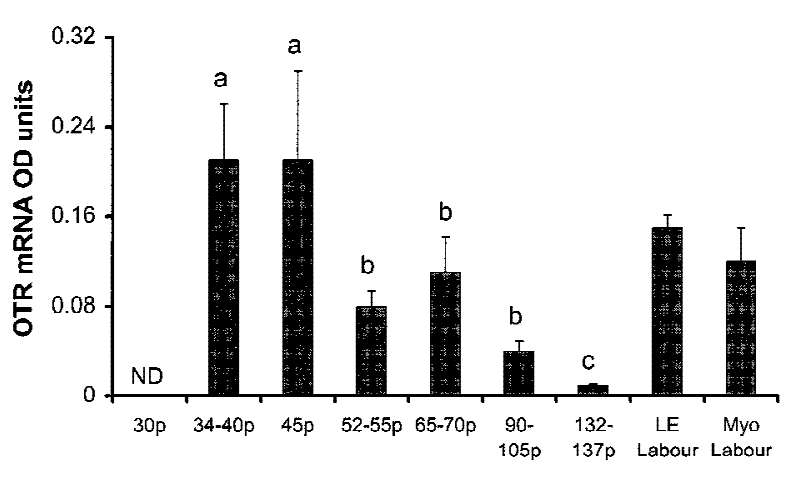

Pregnancy stage (Day)

Figure 7 OTR mRNA expression in the placentome was investigated throughout pregnancy at regular intervals $(p ; n=3-7$ per stage) using in situ hybridisation. The results were expressed as OD units \pm S.E.M.. No OTR mRNA expression was detected before day 34 of pregnancy (ND). A significant up-regulation of OTR mRNA in the placentome capsule on days 34-45 of pregnancy was observed, which dropped to a lower level by day 52 and then progressively decreased to basal levels by day 132 of pregnancy. ( $\mathrm{a}>\mathrm{c}, P<0.0001 ; \mathrm{b}>\mathrm{c}, P<0.05 ; \mathrm{a}>\mathrm{b}, P<0.05)$. The concentration of OTR mRNA in the uterine LE and myometrium (Myo) in labour is included to illustrate the relative degree of OTR expression in the placentome capsule throughout pregnancy.

concentrations of oestrogen and progesterone have been measured throughout pregnancy (Bassett et al. 1969, Carnegie \& Robertson 1978), little is known about the development of their receptors in the placenta during most of gestation. Both oxytocin and its receptor are believed to be inhibited and stimulated by progesterone and oestrogen respectively, presumably through binding to their corresponding receptors. This study provides the first description of the relative expression pattern of aromatase, progesterone receptor, oestradiol receptor, oxytocin and OTR in the ovine placentome throughout pregnancy and, therefore, clarifies the possible roles of progesterone receptor and oestradiol receptor on the expression of OTR during pregnancy.

Aromatase catalyses the last step in the conversion of progesterone to oestrogen. Aromatase activity is thus critical to the biosynthesis of oestrogen. Previous studies in ovine placental tissues show that the catalytic activity of aromatase is increased significantly near term (Mason et al. 1989), which is consistent with the findings of this study. However, our results differ from those of Tsumagari et al. (1993) in bovine cotyledon who observed that the catalytic activity of aromatase peaked in mid-gestation around the fifth month and immediately after, but not before, parturition. This discrepancy may be due to a species difference. Another possibility is that the aromatase catalytic activity may not be proportional to its mRNA concentration in the cow, although the aromatase mRNA in this study peaked in parallel to its reported catalytic activity in sheep (Mason et al. 1989).
The constant expression of aromatase in early pregnancy (after day 34) and the significant up-regulation in late pregnancy in the fetal villi may explain the gradual increase in oestradiol sulphate in both the fetal and maternal system, which also show a significant increase preceding the onset of parturition (Carnegie \& Robertson 1978). Since the aromatase mRNA is of fetal origin, it suggests that the maternal oestrogen level may be modulated by the fetus as gestation progresses. Cortisol has been implicated as the transcriptional stimulator of aromatase at term (Flint et al. 1975, Ricketts et al. 1980, Mason et al. 1989). Our results support this hypothesis but cortisol may not be the sole transcriptional stimulator since aromatase mRNA was expressed throughout most of the gestation period. It has been reported that a non-steroidal aromatase inhibitor is produced and secreted by the corpus luteum and placenta in sheep during the last third of gestation (Al-Gubory et al. 1994, 1995). Withdrawal of such an inhibitor would allow a quick increase in oestradiol synthesis. Therefore, it seems likely that the activity of aromatase is strictly regulated at both the transcriptional and post-translational levels.

The results from this study suggest that the expression of oestradiol receptor was unlikely to be regulated solely by oestradiol. The expression of oestradiol receptor in the placentome follows a tissue and time specific pattern during gestation. The up-regulation of oestradiol receptor mRNA in the capsule of the placentome between days 45 and 65 corresponds to the appearance of oestradiol sulphate found in the fetal and maternal systems, although the concentration of free oestradiol is low at this stage. In addition, oestradiol receptor mRNA concentration in this tissue dropped below the detection limit by day 90 of pregnancy until term although the oestradiol sulphate and free oestradiol continue to increase until parturition. This suggests that an unknown stimulus may be produced by the placental system to regulate the transcriptional expression of oestradiol receptor during pregnancy. More importantly, only a limited amount of oestradiol receptor protein was localised in the placentome capsule from days 40 to 105 whereas its mRNA was high up to day 65 and dropped below the detection limit by day 90 of pregnancy. This suggests that the expression of oestradiol receptor may also be regulated at the translational level and that a very low concentration of oestradiol receptor protein may be sufficient to serve its purpose throughout pregnancy.

The inhibition of the expression of OTR by interferon $\gamma$ in early pregnancy is essential to prevent luteolysis (for reviews see Stewart et al. 1992, Flint et al. 1994). This may in part be via down-regulating the concentration of oestradiol receptor (Mirando et al. 1993, Spencer et al. 1995a,b). This study showed that a low level of oestradiol receptor mRNA is present on days 13-15 of pregnancy in the caruncle and the LE, suggesting that a basal 
activity of oestradiol receptor may still be required during implantation.

After implantation, the trophoblast stops producing interferon and the expression of uterine OTR resumes. Its concentration remained at a low but detectable level in the endometrial LE throughout gestation, with a small increase at mid-pregnancy and a significant up-regulation during parturition (Wathes et al. 1996a). In contrast, the concentration of oestradiol receptor in the LE was below the detection limit during most of the gestation period and only a low concentration was measured at parturition (Leung et al. 1997). This suggests that the expression of OTR in the LE may occur in a constitutive and inducible manner such that the oestradiol receptor is only required to facilitate the significant up-regulation of OTR expression. Furthermore, the expression of OTR mRNA preceded that of the oestradiol receptor in the placentome capsule in mid-pregnancy, confirming that the oestradiol receptor is not the main stimulus for the induction of OTR expression. However, the oestradiol receptor may be required to sustain OTR expression. It has been demonstrated that oestradiol can both stimulate and suppress OTR expression in the uterus of cyclic sheep (Wathes \& Lamming 1995), supporting the hypothesis that oestradiol has a differential regulatory effect on OTR expression. We have previously reported that OTR follows a similar expression pattern to that of oestradiol receptor in the caruncular stroma, myometrium and cervix of cyclic sheep whereas OTR expression in the LE is not correlated with oestradiol receptor expression (Wathes \& Hamon 1993, Leung et al. 1995). In addition, OTR expression in the uterus and cervix are highly coordinated in cyclic ewes with maximal expression in both tissues at oestrus but such coordination is absent during parturition when the increase only occurs in the uterus (Leung et al. 1995, Wathes et al. 1996a). This suggests that tissue specific factor(s) are required to regulate OTR expression. If the presence of such local regulatory factor(s) is confirmed, the steroidal effect on OTR expression in some tissues may be mediated through modifying the activity of these regulatory agent(s). This may provide an explanation of the differential expression of OTR in a tissue and time specific manner.

Oxytocin, mediated by OTR, is able to induce the production of $\mathrm{PGF}_{2 \alpha}$ and $\mathrm{PGE}_{2}$ in the placental tissues (Moore et al. 1988, Meier et al. 1995, Fuchs et al. 1996). $\mathrm{PGE}_{2}$ can stimulate vascular dilation (Armstrong et al. 1995) whereas $\mathrm{PGF}_{2 \alpha}$ may promote placental growth since $\mathrm{PGF}_{2 \alpha}$ treatment increases the placentome weights at days 90-100 of pregnancy (Weems et al. 1994). The significant increase in OTR expression, possibly supported by oestradiol receptors, in the placentome capsule coincides with the time of the fastest placentome growth rate at around day 40 (Amoroso 1952). In addition, the peak of OTR and oestradiol receptor expression in the placentome capsule coincided with the sudden onset of regular mus- cular contractility in the pregnant horn of the uterus from days 49 to 66. No uterine activity was detectable before day 41 and only steady uterine activity was detected after day 66 until parturition (Garcia-Villar et al. 1984). This suggests that OTR may be responsible for the induction of uterine activity during pregnancy but the function of this activity is unclear.

The lack of oxytocin expression in the placental tissues confirms our previous results (Wathes et al. 1996a) and suggests that an oxytocin paracrine/autocrine system within the uterus may be absent in sheep. Nevertheless, the pituitary may provide the source of oxytocin since a basal level of oxytocin was measurable in human serum throughout pregnancy (Leake et al. 1981) and a low pulsatile secretion of oxytocin was also found in pregnant cows (Fuchs et al. 1986).

A high progesterone concentration plays an essential role in maintaining pregnancy, including stimulating uterine secretions (Stephenson et al. 1989), acting as an immunosuppressant (Stites \& Siteri 1983) and inhibiting myometrial contractions. Previous workers have shown that immunoreactive progesterone receptor was present in early pregnancy up to day 21 in the stroma but not in the LE (Wathes \& Hamon 1993, Zheng et al. 1996). In this study, progesterone receptor mRNA was present in the caruncular tissues in early pregnancy on day 30 but became undetectable during the rest of gestation. It is possible, however, that progesterone may act at another site external to the placenta. Another possibility is that the technique used in this study was not sensitive enough to detect very low expression of progesterone receptor mRNA. Nevertheless, the drop in progesterone receptor mRNA by day 35 preceded the up-regulation of aromatase and OTR mRNA at days 35-40, strongly suggesting that progesterone receptor may have an inhibitory effect on the expression of OTR and aromatase in the placentome during early pregnancy.

In conclusion, the expression of aromatase, which parallels the concentration of oestrogenic derivatives during pregnancy, and OTR may be inhibited by progesterone receptor during early pregnancy. The expression of oestradiol receptor may be regulated at both the transcriptional and translational levels in a tissue and time specific manner, independent of the concentration of free oestradiol in the circulation and may be unaffected by progesterone receptor. Finally, the results from this study show that the up-regulation of OTR in the placentome capsule precedes the appearance of the oestradiol receptor, and is therefore unlikely to be regulated directly by oestradiol.

\section{Acknowledgements}

We are grateful to John Thompson and David Manners for care of the animals. Mr Leung was supported by the Royal 
Veterinary College and the study was funded in part by the BBSRC and the Wellcome Trust.

\section{References}

Al-Gubory KH, Driancourt MA, Antoine M, Martal J \& Neimer N 1994 Evidence that a non-steroidal factor from corpus luteum of pregnant sheep inhibits aromatase activity of ovarian follicles in vitro. Journal of Reproduction and Fertility 100 51-56.

Al-Gubory KH, Machelon V \& Nome F 1995 Evidence that a non-steroidal factor from ovine placenta inhibits aromatase activity of granulosa cells in vitro. Comptes Rendus De L'Academie Des Sciences. Serie III, Sciences De La Vie/Life Science 318 91-98.

Amoroso EC 1952 Placentation. In Marshall's Physiology of Reproduction, edn 3, pp 127-311. Ed AS Parkes. London: Longmans Press.

Armstrong RA, Marr C \& Jones RL 1995 Characterization of the EP-receptor mediating dilatation and potentiation of inflammation in rabbit skin. Prostaglandins 49 205-224.

Bassett JM, Thorburn GD \& Oxborrow TJ 1969 The concentration of progesterone in the peripheral plasma of the pregnant ewe. Journal of Endocrinology 45 449-457.

Carnegie JA \& Robertson HA 1978 Conjugated and unconjugated estrogens in fetal and maternal fluids of the pregnant ewe: a possible role for estrone sulfate during early pregnancy. Biology of Reproduction 19 202-211.

Cheah SH, Ng KH, Johgalingam VT \& Ragavan M 1995 The effects of oestradiol and relaxin on extensibility and collagen organisation of the pregnant rat cervix. Journal of Endocrinology 146 331-337.

Chibbar R, Hobkirk R \& Mitchell BF 1986 Sulfohydrolase activity for estrone sulfate and dehydroepiandrosterone sulfate in human fetal membranes and decidua around the time of parturition. Journal of Clinical Endocrinology and Metabolism 62 90-94.

Ciray HN, Backstrom T, Ulmsten U \& Roomans GM 1996 Steroid hormone effect on intercellular communication between term pregnant human myometrial cells before labor. Biology of Reproduction 55 379-385.

Ellwood DA 1980 The hormonal control of connective-tissues changes in the uterine cervix in pregnancy and at parturition. Biochemical Society Transactions 8 662-667.

Fang X, Wong S \& Mitchell B F 1996 Relationships among sex steroids, oxytocin, and their receptors in the rat uterus during late gestation and at parturition. Endocrinology 137 3213-3219.

Flint APF, Ricketts AP \& Craig VA 1975 The control of placental steroid synthesis at parturition in domestic animals. Animal Reproduction Science 2 239-251.

Flint APF, Lamming GE, Stewart HJ \& Abayasekara DRE 1994 The role of the endometrial oxytocin receptor in determining the length of the sterile oestrous cycle and ensuring maintenance of luteal function in early pregnancy in ruminants. Philosophical Transactions of the Royal Society of London. Series B: Biological Sciences 344 291-304.

Fuchs AR, Gimenez T, Ganz NI \& Fields MJ 1986 Pulsatile release of oxytocin in pregnant and parturient cows. In Program of the 33rd Annual Meeting of the Society of Gynecology Investigation, March 19-21, Toronto, Ontario, Canada, A153.

Fuchs AR, Helmer H, Behrens O, Liu HC, Antonian L, Chang SM \& Fields MJ 1992 Oxytocin and bovine parturition: a steep rise in endometrial oxytocin receptors precedes onset of labor. Biology of Reproduction 47 937-944.

Fuchs AR, Rollyson MK, Meyer MM, Fields MJ, Minix JM \& Randel RD 1996 Oxytocin induces prostaglandin $F_{2 \alpha}$ release in pregnant cows: influence of gestational age and oxytocin receptor concentration. Biology of Reproduction 54 647-653.

Garcia-Villar R, Toutain PL \& Ruckebusch Y 1984 Pattern of electrical activity of the ovine uterus and cervix from mating to parturition. Journal of Reproduction and Fertility 72 143-152.
Garfield RE, Kaman HS \& Daniel EE 1980 Gap junction formation in myometrium: control by estrogens, progesterone and prostaglandin. American Journal of Physiology 7 C81-C89.

Hinshelwood MM, Liu Z, Conley AJ \& Simpson ER 1993 Demonstration of tissue-specific promoter in nonprimates species that express aromatase P450 in placenta. Biology of Reproduction 53 $1151-1159$

Ing NH \& Tornesi MB 1997 Estradiol up-regulates estrogen receptor and progesterone receptor gene expression in specific ovine uterine cells. Biology of Reproduction 56 1205-1215.

Ing NH, Spencer TE \& Bazer FE 1996 Estrogen enhances endometrial estrogen receptor gene expression by a posttranscriptional mechanism in the ovariectomized ewe. Biology of Reproduction 54 591-599.

Ivell R, Hunt N, Abend N, Brackman B, Nollmeyer D, Lamsa JC \& McCracken JA 1990 Structure and ovarian expression of the oxytocin gene in sheep. Reproduction, Fertility, and Development 2 703-711.

Janszen BPM, Bevers MM, Van-Tol HTM, Dieleman SJ, Van-der-Weijden GC \& Taverne MAM 1995 Oestrogen sulphatase activity in endometrium and foetal membranes of late gestational and parturient cows. Animal Reproduction Science 37 251-256.

Katzenellenbogen BS 1996 Estrogen receptors: bioactivities and interactions with cell signalling pathways. Biology of Reproduction $\mathbf{5 4}$ 287-293.

Kimura T, Takemura M, Nomura S, Nobunaga T, Kubota Y, Inoue T, Hashimoto K, Kumazawa I, Ito Y, Ohashi K, Koyama M, Azuma C, Kitamura Y \& Saji F 1996 Expression of oxytocin receptor in human pregnant myometrium. Endocrinology 137 780-785.

Larcher A, Neculcea J, Breton C, Arslan A, Rozen F, Russo C \& Zingg HH 1995 Oxytocin receptor gene expression in the rat uterus during pregnancy and the estrous cycle and in response to gonadal steroid treatment. Endocrinology 136 5350-5356.

Leake RD, Weitzman RE, Glatz TH \& Fisher DA 1981 Plasma oxytocin concentration in man, non-pregnant women and pregnant women before and during spontaneous labor. Journal of Clinical Endocrinology and Metabolism $\mathbf{5 3}$ 730-733.

Leung ST, Stevenson KR, Perks C \& Wathes DC 1995 Oxytocin receptor mRNA localization in the cervix of ewes. Journal of Reproduction and Fertility. Abstract Series 16: abstract 55.

Leung ST, Borwick SC, Thornton S, Young IR, Jenkin G \& Wathes DC 1997 Oestradiol receptors do not show a major up-regulation during labour in either sheep or women. Journal of Reproduction and Fertility. Abstract Series 19: abstract 115.

Maggi M, Fantoni G, Peri A, Giannini S, Brandi ML, Orlando C \& Serio M 1991 Steroid modulation of oxytocin/vasopressin receptors in the uterus. Journal of Steroid Biochemistry and Molecular Biology 40 481-491.

Mason JI, France JT, Magness RR, Murray BA \& Rosenfeld CR 1989 Ovine placental steroid $17 \alpha$-hydroxylase/C-17,20-lyase, aromatase and sulphatase in dexamethasone-induced and natural parturition. Journal of Endocrinology 122 351-359.

Meier S, Lau TM, Jenkin G \& Fairclough RJ 1995 Oxytocin induced prostaglandin $\mathrm{F}_{2 \alpha}$ release and endometrial oxytocin receptor concentrations throughout pregnancy in the ewe. Journal of Reproduction and Fertility 103 233-238.

Mitchell BF, Cross J, Hobkirk R \& Challis JRG 1984 Formation of unconjugated estrogens from estrone sulfate by dispersed cells from human fetal membranes and decidua. Journal of Clinical Endocrinology and Metabolism 58 845-849.

Mirando MA, Harney JP, Zhou Y, Ogle TF, Ott TL, Moffatt RJ \& Bazer FW 1993 Changes in progesterone and oestrogen receptor mRNA and protein and oxytocin receptors in endometrium of ewes after intrauterine injection of ovine trophoblast interferon. Journal of Molecular Endocrinology 10 185-192. 
Moore JJ, Dubyak GR, Moore RM \& Kooy DV 1988 Oxytocin activates the inositol-phospholipid-protein kinase-C system and stimulates prostaglandin production in human amnion cells. Endocrinology 123 1771-1777.

Ostrowski NL, Young WS \& Lolait SJ 1995 Estrogen increases renal oxytocin receptor gene expression. Endocrinology 136 1801-1804.

Owiny JR, Mitchell M \& Nathanielsz PW 1992 Effect of 48-h infusion of the synthetic oxytocin antagonist, [1- $\beta$-Mercapto(B-(CH2)5)1(OMe)Tyr2,Orn]-oxytocin, on myometrial activity of pregnant sheep at 139-140 days of gestation. Biology of Reproduction 47 436-440.

Ricketts AP, Gall AKA, Ackland N, Heap RB \& Flint APF 1980 Activation by corticosteroids of steroid metabolizing enzymes in ovine placental explants in vitro. Journal of Endocrinology 85 457-469.

Silva LDM, Onclin K \& Verstegen JP 1995 Cervical opening in relation to progesterone and oestradiol during heat in beagle bitches. Journal of Reproduction and Fertility 104 85-90.

Spencer TE, Becker WC, George P, Mirando MA, Ogle TF \& Bazer FW 1995a Ovine interferon-tau inhibits estrogen receptor up-regulation and estrogen-induced luteolysis in cyclic ewes. Endocrinology $1364932-4944$.

Spencer TE, Ing NH, Ott TL, Mayes JS, Becker WC, Watson GH, Mirando MA \& Bazer FW 1995 Intrauterine injection of ovine interferon-tau alters oestrogen receptor and oxytocin receptor expression in the endometrium of cyclic ewes. Journal of Molecular Endocrinology 15 203-220.

Stephenson DC, Leslie MV, Low BG, Newton GR, Hansen PJ \& Bazer FW 1989 Secretion of the major progesterone-induced proteins of the sheep uterus by caruncular and intercaruncular endometrium of the pregnant ewe from days 20-140 of gestation. Domestic Animal Endocrinology 6 349-362.

Stevenson KR, Riley PR, Stewart HJ, Flint APF \& Wathes DC 1994 Localisation of oxytocin receptor mRNA in the ovine uterus during the oestrous cycle and early pregnancy. Journal of Molecular Endocrinology 12 93-105.

Stewart HJ, Guesdon FMJ, Payne JH, Charleston B, Vallet JL \& Flint APF 1992 Trophoblast interferons in early pregnancy of domestic ruminants. Journal of Reproduction and Fertility. Supplement 45 59-68.

Stites DP \& Siteri PK 1983 Steroids as immunosuppressants in pregnancy. Immunological Reviews 75 117-138.

Tsumagari S, Kamata J, Takagi K, Tanemura K, Yosai A \& Takeishi M 1993 Aromatase activity and oestrogen concentration in bovine cotyledons and caruncles during gestation and parturition. Journal of Reproduction and Fertility 98 631-636.
Wathes DC \& Hamon M 1993 Localisation of oestradiol, progesterone and oxytocin receptors in the uterus during the oestrous cycle and early pregnancy of the ewe. Journal of Endocrinology 138 479-491.

Wathes DC \& Lamming GE 1995 The oxytocin receptor, luteolysis and the maintenance of pregnancy. Journal of Reproduction and Fertility. Supplement 49 53-67.

Wathes DC, Flick-Smith H, Leung ST, Stevenson KR, Meier S \& Jenkin G 1996a Oxytocin receptor development in ovine uterus and cervix throughout pregnancy and at parturition as determined by in situ hybridisation analysis. Journal of Reproduction and Fertility $10623-31$.

Wathes DC, Mann GE, Payne JH, Riley PR, Stevenson KR \& Lamming GE $1996 b$ Regulation of oxytocin, oestradiol and progesterone receptor concentrations in different uterine regions by oestradiol, progesterone and oxytocin in ovariectomized ewes. Journal of Endocrinology 151 375-393.

Weems YS, Sasser RG, Vincent DL, Nusser KD, Tanaka Y, Miller-Patrick K, Ledgerwood KS \& Weems CW 1994 Effects of prostaglandin $\mathrm{F}_{2 \alpha}\left(\mathrm{PGF}_{2 \alpha}\right)$ on secretion of pregnancy specific protein B (PSPB) and placentome weights in intact or ovariectomized 90 to 100 day pregnant ewes. Prostaglandins $\mathbf{4 8}$ 377-387.

Winn RJ, Baker MD \& Sherwood OD 1994 Individual and combined effects of relaxin, estrogen, and progesterone in ovariectomized gilts. I. Effects on the growth, softening, and histological properties of the cervix. Endocrinology 135 1241-1249.

Word RA, Kamm KE \& Casey ML 1992 Contractile effects of prostaglandins, oxytocin, and endothelin-1 in human myometrium in vitro: refractoriness of myometrial tissue of pregnant women to prostaglandins $\mathrm{E}_{2}$ and $\mathrm{F}_{2 \alpha}$. Journal of Clinical Endocrinology and Metabolism 75 1027-1032.

Wu WX, Verbalis JG, Hoffman GE, Derks JB \& Nathanielsz PW 1996 Characterization of oxytocin receptor expression and distribution in the pregnant sheep uterus. Endocrinology 137 $722-728$.

Zheng J, Johnson ML, Redmer DA \& Reynolds LP 1996 Estrogen and progesterone receptors, cell proliferation, and $\mathrm{c}$-fos expression in the ovine uterus during early pregnancy. Endocrinology 137 340-348.

Received 18 December 1997

Revised manuscript received 5 March 1998 Accepted 16 March 1998 